\title{
PEMBERIAN ASI EKSLUSIF PADA BAYI USIA 4-6 BULAN DI PUSKESMAS RANGKASBITUNG KAB. LEBAK TAHUN 2014
}

\author{
*Yayah Rokayah
}

\begin{abstract}
Abstrak
Pemberian Air Susu Ibu (ASI) sejak lahir merupakan modal dasar dalam pembentukan manusia berkualitas, terutama pemberian ASI ekslusif yaitu pemberian ASI kepada bayi sejak lahir sampai dengan usia bayi 6 bulan. ASI merupakan makanan yang paling sempurna, karena kandungan gizi dalam ASI sesuai dengan kebutuhan untuk pertumbuhan dan perkembangan yang optimal. Analisis di 6 negara berkembang menunjukan ada perbedaan antara bayi yang mendapatkan ASI dengan yang tidak diberi ASI terhadap risiko kematian akibat penyakit infeksi. Penelitian ini bertujuan untuk menganalisis faktor-faktor yang yang berhubungan dengan kelangsungan pemberian ASI ekslusif pada bayi usia 46 bulan di Desa Rangkasbitung Barat Puskesmas Rangkasbitung. Metode yang digunakan adalah survei dengan pendekatan Cross sectional. Populasinya adalah semua ibu yang mempunyai bayi $>6$ bulan yang sudah diberikan ASI ekslusif s.d 4 bulan yang tercatat di buku register ibu dan anak, Sampel yang diambil secara proporsif sebanyak 37 orang.

Hasil penelitian yang dilakukan menunjukan bahwa variabel pengetahuan, pengalaman menyusui dan dukungan tenaga kesehatan mempunyai hubungan dengan kelangsungan pemberian ASI Ekslusif pada bayi usia 4 sampai 6 bulan. sedangkan variable yang paling erat hubungannya dengan kelangsungan pemberian ASI ekslusif adalah dukungan tenaga kesehatan dengan $\alpha 0.004$. berdasarkan hasil tersebut disarankan motivasi bidan lebih ditingkatkan lagi dalam memberikan penyuluhan maupun konseling sehingga pengetahuan ibu-ibu mengenai ASI ekslusif menjadi lebih baik.
\end{abstract}

\section{Kata Kunci : ASI Eksklusif, bayu usia 4-6 bulan}

*Dosen Jurusan kebidanan Poltekkes Kemenkes Banten 


\section{Pendahuluan}

Pemberian ASI ditujukan untuk memenuhi kebutuhan dasar biologis anak, sebagai hak azasi anak, meningkatkan mutu sumberdaya manusia juga dapat membina hubungan kasih sayang antara ibu dan bayinya. Bagi bayi ASI merupakan makanan yang paling sempurna, karena kandungan gizi dalam ASI sesuai dengan kebutuhan untuk pertumbuhan dan perkembangan yang optimal.

ASI juga mengandung zat untuk perkembangan kecerdasan serta zat kekebalan (mencegah dari berbagai penyakit). Di Indonesia banyak factor yang berpengaruh pada pemberian ASI Ekslusif yaitu factor ibu, factor bayi dan factor lingkungan.

Pentingnya pemberian ASI didasarkan atas temuan bahwa bayi yang mendapatkan ASI Ekslusif mempunyai risiko yang paling rendah terhadap infeksi yang umum terjadi pada bayi dibandingkan bayi yang tidak mendapatkan ASI ekslusif. Analisis di 6 negara berkembang menunjukkan ada perbedaan antara bayi yang mendapatkan ASI dengan yang tidak diberi ASI terhadap risiko kematian akibat penyakit infeksi.

Hasil penelitian di Bogor tahun 2001 menunjukan bahwa anak yang diberi ASI Ekslusif sampai usia 4 bulan tidak ada yang menderita gizi buruk ketika mereka berusia 5 tahun. Penelitian yang sama menunjukan bahwa $18,7 \%$ ibu-ibu dianjurkan oleh petugas kesehatan untuk memberikan susu formula pada minggu pertama setelah melahirkan, $76 \%$ ibu menyatakan sumber promosi susu formula adalah tempat pelayanan kesehatan ( iklan susu formula di rumah sakit, praktek klinik swasta, puskesmas), lebih $60 \%$ ibu menerima susu formula bayi melalui Rumah Sakit atau Rumah Bersalin, 14,8\% bidan menyatakan setuju untuk memberikan susu formula kepada bayi baru lahir.

Kegagalan dalam pemberian ASI Ekslusif disebabkan oleh kurangnya pengetahuan ibu tentang keuntungan menyusui dan kerugian memberikan makanan selain ASI sebelum waktunya serta ketidaktahuan ibu mengenai teknik menyusui yang baik dan benar. 
Kurangnya pemberian pengertian dan keterampilan oleh petugas kesehatan tentang keunggulan ASI dan manfaat menyusui menyebabkan ibu mudah terpengaruh oleh promosi susu formula yang sering dinyatakan sebagai pengganti ASI (PASI). Ibu yang mempunyai informasi atau pengetahuan yang kurang mengenai ASI akan merasa kurang percaya diri atau kurang yakin bahwa ASI akan mencukupi kebutuhan bayi. Ibu juga lebih mudah terpengaruh dengan berbagai macam promosi susu formula, karena kepraktisannya, sehingga banyak ibuibu yang bekerja lebih memilih untuk memberikan susu formula kepada anaknya. pengetahuan dan pengalaman yang dimiliki oleh ibu akan mempengaruhi sikap dan penampilan mereka dalam kaitannya dengan menyusui.

Kegagalan ibu dalam praktek pemberian ASI Ekslusif dapat juga disebabkan oleh proses menyusui yang tidak lancar, antara lain karena ibu stres atau cemas pada awal menyusui, menyususi hanya dengan satu sisi payudara, ibu tidak mau menyusui karena takut gemuk
Manfaat penelitian diharapkan dapat memberikan masukan bagi pengelola program gizi di Puskesmas dalam rangka meningkatkan cakupan ASI Ekslusif melalui upaya peningkatkan pemberian Air Susu Ibu (PP-ASI) yang berkesinambungaan dan dengan melakukan penelitian ini peneliti dapat meningkatkan kemampuan praktis dalam penelitian khususnya dalam hal kelangsungan pemberian ASI ekslusif.

\section{Metodologi Penelitian}

Penelitian ini menggunakan pendekatan kuantitatif. Pelaksanaan penelitian dirancang dengan metode analitik. Metode yang digunakan adalah survei dengan pendekatan Cross sectional. Populasinya adalah semua ibu yang mempunyai bayi $>6$ bulan yang sudah diberikan ASI ekslusif s.d minimal 4 bulan yang tercatat di buku register ibu dan anak.

Sampel yang diambil secara proporsif sebanyak 37 orang, yang terdiri dari ibu yang menyusuai secara eksklusif sampai usia bayi 6 bulan, dan ibu yang menyusuai kurang dari 6 bulan (antara 4 s.d hamper 6 bulan). 
Instrument penelitian menggunakan kuesioner

Jenis data yang dikumpulkan adalah menggunakan data primer yaitu dengan cara menanyakan langsung pada responden. Analisis data dilakukan dengan cara analisis univariat dan bivariat dengan $C h i$ Square.

\section{Hasil Penelitian}

\section{Pendidikan Responden}

Tabel 1.

Distribusi Frekuensi Ibu Menyusui Berdasarkan Tingkat Pendidikan

\begin{tabular}{lll}
\hline $\begin{array}{c}\text { Pendidikan } \\
\text { Ibu }\end{array}$ & F & $\%$ \\
\hline Tinggi & 20 & 54,1 \\
\hline Rendah & 17 & 45.9 \\
\hline Jumlah & 37 & 100
\end{tabular}

Tabel 1 menunjukkan bahwa hamper sebagian ibu menyusui $(45,9 \%)$ memiliki tingkat pendidikan rendah (SLTP kebawah).

\section{Pengetahuan Responden tentang}

\section{Pemberian ASI Eksklusif}

Tabel 2

Distribusi Frekuensi Ibu Menyusui Berdasarkan Pengetahuan Ibu Tentang Pemberian ASI ekslusif

\begin{tabular}{lcc}
\hline \multicolumn{1}{c}{ Pengetahuan } & F & $\%$ \\
\hline Baik & 28 & 75.5 \\
\hline Kurang & 9 & 24.3 \\
\hline Jumlah & 37 & 100 \\
\hline
\end{tabular}

Tabel 2 menunjukkan bahwa masih banyak $(24,3 \%)$ terdapat ibu menyusui yang memiliki pengetahuan kurang tentang pemberian ASI eksklusif

\section{Sikap Responden terhadap Pemberian ASI Eksklusif}

Tabel 3

Distribusi Frekuensi Ibu Menyusui Berdasarkan Sikap Ibu Terhadap Pemberian ASI Ekslusif

\begin{tabular}{lcc}
\hline Sikap responden & F & $\%$ \\
\hline Setuju & 2 & 5.4 \\
\hline Tidak setuju & 35 & 94.6 \\
\hline Jumlah & 37 & 100 \\
\hline
\end{tabular}

Tabel 3 bahwa hamper seluruh ibu menyusui $(94,6 \%)$ memiliki sikap tidak setuju terhadap pemberian ASI secara eksklusif.

\section{Pekerjaan Responden}

Tabel 4

Distribusi Frekuensi Ibu Menyusui Berdasarkan Pekerjaan Ibu

\begin{tabular}{lcc}
\hline Pekerjaan Ibu & F & $\%$ \\
\hline Bekerja & 5 & 13.5 \\
\hline Tidak bekerja & 32 & 86.5 \\
\hline Jumlah & 37 & 100 \\
\hline
\end{tabular}

Table 4 menunjukkan bahwa sebagian besar $(86.5 \%)$ ibu menyusui tidak memiliki pekerjaan tetap (tidak bekerja) 


\section{Pengalaman Menyusui}

\section{Responden}

Tabel 5

Distribusi Frekuensi Ibu Menyusui Berdasarkan Pengalaman Menyusui

\begin{tabular}{lcc}
\hline $\begin{array}{c}\text { Pengalaman } \\
\text { Menyusui }\end{array}$ & F & $\%$ \\
\hline Pernah & 31 & 83.8 \\
\hline Tdk pernah & 6 & 16.2 \\
\hline Jumlah & 37 & 100 \\
\hline
\end{tabular}

Tabel 5 menunjukkan bahwa masih terdapat $16,2 \%$ ibu menyusui yang belum pernah memiliki pengalaman menyusui bayi.

\section{Dukungan Keluarga Responden}

Tabel 6

Distribusi Frekuensi Ibu Menyusui Berdasarkan Dukungan Keluarga Terhadap Penerapan ASI Ekslusif

\begin{tabular}{lcc}
\hline Dukungan keluarga & $\mathrm{F}$ & $\%$ \\
\hline Mendukung & 19 & 51.4 \\
\hline Tidak Mendukung & 18 & 48.6 \\
\hline Jumlah & 37 & 100 \\
\hline
\end{tabular}

Tabel 6 menunjukkan bahwa hamper sebagian $(48,6 \%)$ keluarga ibu menyusui tidak mendukung terhadap penerapan atau pelaksanaan ASI Eksklusif.

\section{Dukungan Tenaga Kesehatan}

Tabel 7

Distribusi Frekuensi Ibu Menyusui Berdasarkan Dukungan Tenaga Kesehatan Terhadap Pemberian ASI Ekslusif

\begin{tabular}{lcc}
\hline \multicolumn{1}{c}{ Dukungan Nakes } & $\mathrm{F}$ & $\%$ \\
\hline Mendukung & 30 & 81.1 \\
\hline Tidak mendukung & 7 & 18.9 \\
\hline Jumlah & 37 & 100 \\
\hline
\end{tabular}

Tabel 7 menunjukkan bahwa masih terdapat $(18,9 \%)$ ibu menyusui yang menyatakan belum mendapat dukungan dari tenaga kesehatan untuk pemberian ASI Eksklusif.

\section{Pemberian ASI Eksklusif}

Tabel 8

Distribusi Frekuensi Ibu Menyusui Berdasarkan Pemberian ASI Ekslusif

\begin{tabular}{lcc}
\hline $\begin{array}{c}\text { Pemberian ASI } \\
\text { Ekslusif }\end{array}$ & F & $\%$ \\
\hline Ekslusif & 19 & 51.4 \\
\hline Tidak ekslusif & 18 & 48.6 \\
\hline Jumlah & 37 & 100 \\
\hline
\end{tabular}

Tabel 8 menunjukkan bahwa hamper sebagian $(48,6 \%)$ ibu menyusui tidak melakukan pemberian ASI secara tidak eksklusif. 


\section{Hubungan Pendidikan dengan Pemberian ASI Eksklusif}

Tabel 9

Distribusi Frekuensi Ibu Menyusui Berdasarkan Tingkat Pendidikan dan Pemberian ASI Ekslusif

\begin{tabular}{ccccccc}
\hline \multirow{2}{*}{ Pddkan } & \multicolumn{3}{c}{ Prilaku Responden } & \multicolumn{2}{c}{ Total } \\
\cline { 2 - 6 } & \multicolumn{2}{c}{$\begin{array}{c}\text { Tidak } \\
\text { ekslusif }\end{array}$} & \multicolumn{2}{c}{ Ekslusif } & \multicolumn{2}{c}{ Total } \\
\cline { 2 - 6 } & $\mathrm{n}$ & $\%$ & $\mathrm{~N}$ & $\%$ & $\mathrm{n}$ & $\%$ \\
\hline Rendah & 10 & 58.8 & 7 & 41.2 & 17 & 100 \\
\hline Tinggi & 8 & 40.0 & 12 & 60.0 & 20 & 100 \\
\hline Total & 18 & 48.6 & 19 & 51.4 & 37 & 100 \\
\hline \multicolumn{8}{c}{$p=0,254$} \\
\hline
\end{tabular}

Secara deskriptif tabel 9 menunjukkan bahwa ibu menyusui yang tidak memberikan ASI secara eksklusif lebih banyak $(58,8 \%)$ terjadi pada ibu yang berpendidikan rendah (SLTP kebawah), bila dibandingkan dengan ibu yang berpendidikan tinggi (SLTA keatas) hanya $40,0 \%$ yang tidak memberikan ASI secara eksklusif.

\section{Hubungan Pengetahuan dengan}

\section{Pemberian ASI Eksklusif}

Tabel 10

Distribusi Frekuensi Ibu Menyusui Berdasarkan Pengetahuan dan Pemberian ASI Ekslusif

\begin{tabular}{|c|c|c|c|c|c|c|c|}
\hline \multirow{3}{*}{ Pngthuan } & \multicolumn{4}{|c|}{ Perilaku Responden } & \multirow{2}{*}{\multicolumn{2}{|c|}{ Total }} & \\
\hline & \multicolumn{2}{|c|}{$\begin{array}{c}\text { Tidak } \\
\text { ekslusif }\end{array}$} & \multicolumn{2}{|c|}{ Ekslusif } & & & \\
\hline & $\mathrm{N}$ & $\%$ & $\mathrm{n}$ & $\%$ & $\mathrm{n}$ & $\%$ & \\
\hline Kurang & 7 & 77.8 & 2 & 22.2 & 9 & 100 & \\
\hline Baik & 11 & 39.3 & 17 & 60.7 & 28 & 100 & \\
\hline \multicolumn{2}{|c|}{ Total } & 18 & 48.6 & 19 & 51,4 & 37 & 100 \\
\hline \multicolumn{8}{|c|}{$p=0.044$} \\
\hline
\end{tabular}

Tabel 10 menunjukkan bahwa secara deskriptif ibu menyusui yang tidak memberikan ASI secara Eksklusif lebih banyak terjadi $(77,8 \%)$ pada ibu yang berpengetahuan kurang tentang ASI Eksklusif, bila dibandingkan dengan ibu yang memiliki pengetahuan baik tentang ASi Eksklusif hanya 39,3\% yang tidak memberikan ASI secara Eksklusif. Secara bivariat diperoleh nilai $\mathrm{p}$ sebesar $0.044(\mathrm{p}<\alpha)$ dapat diartikan bahwa ada hubungan yang signifikan antara pengetahuan yang ibu miliki tentang ASI eksklusif dengan praktik pemberian ASI ekslusif pada bayinya.

\section{Hubungan Sikap dengan Pemberian ASI Eksklusif}

Tabel 11

Distribusi Frekuensi Ibu Menyusui Berdasarkan Sikap dan Pemberian ASI Ekslusif

\begin{tabular}{ccccccc}
\hline \multirow{3}{*}{ Sikap } & \multicolumn{3}{c}{ Perilaku Responden } & \multirow{2}{*}{ Total } \\
\cline { 2 - 6 } & $\begin{array}{c}\text { Tidak } \\
\text { Ekslusif }\end{array}$ & \multicolumn{2}{c}{ Ekslusif } & & & \\
\cline { 2 - 6 } & $\mathrm{n}$ & $\%$ & $\mathrm{n}$ & $\%$ & $\mathrm{n}$ & $\%$ \\
\hline Kurang & 17 & 48.6 & 18 & 51.4 & 35 & 100 \\
\hline Baik & 1 & 50.0 & 1 & 50.0 & 2 & 100 \\
\hline Total & 18 & 48.6 & 19 & 51.4 & 37 & 100 \\
\hline \multicolumn{7}{c}{$p=0.969$} \\
\hline
\end{tabular}

Berdasarkan tabel silang 11 diketahui bahwa nilai $p$ pada analisis bivariat 
dengan uji chi square adalah 0.969 dapat diartikan bahwa tidak ada hubungan yang signifikan antara sikap dengan pemberian ASI ekslusif.

\section{Hubungan Pekerjaan dengan Pemberian ASI eksklusif}

Tabel 12

Distribusi Frekuensi Ibu Menyusui Berdasarkan Pekerjaan dan Pemberian ASI Ekslusif

\begin{tabular}{|c|c|c|c|c|c|c|}
\hline \multirow{4}{*}{ Pkrjn } & \multirow{2}{*}{\multicolumn{4}{|c|}{ Perilaku Responden }} & \multirow{2}{*}{\multicolumn{2}{|c|}{ Total }} \\
\hline & & & & & & \\
\hline & \multicolumn{2}{|c|}{$\begin{array}{l}\text { Tidak } \\
\text { ekslusif }\end{array}$} & \multicolumn{2}{|c|}{ ekslusif } & & \\
\hline & $\mathrm{n}$ & $\%$ & $\mathrm{n}$ & $\%$ & $\mathrm{n}$ & $\%$ \\
\hline Tdk & 17 & 53.1 & 15 & 46.9 & 32 & 100 \\
\hline \multicolumn{7}{|l|}{ Bkerja } \\
\hline Bekerja & 1 & 20.0 & 4 & 80.0 & 5 & 100 \\
\hline Total & 18 & 48.6 & 19 & 51.4 & 35 & 100 \\
\hline
\end{tabular}

Berdasarkan tabel silang 12 diketahui bahwa nilai $p$ pada analisis bivariat dengan uji chi square adalah 0.168 dapat diartikan bahwa tidak ada hubungan yang signifikan antara ibu bekerja dengan pemberian ASI ekslusif; walaupun secara deskriptif menunjukkan bahwa ibu yang tidak bekerja lebih banyak $(53,1 \%)$ yang tidak memberikan ASI secara eksklusif pada bayinya, bila dibandingkan dengan ibu yang bekerja hanya $20,0 \%$ yang tidak memberikan ASI secara eksklusif pada bayinya.

\section{Hubungan Pengalaman Menyusui dengan Pemberian ASI Eksklusif}

Tabel 13

Distribusi Frekuensi Ibu Menyusui Berdasarkan Pengalaman Menyusui dan Pemberian ASI Ekslusif

\begin{tabular}{|c|c|c|c|c|c|c|}
\hline \multirow{3}{*}{ Pengalaman } & \multicolumn{4}{|c|}{ Perilaku Responden } & \multirow{2}{*}{\multicolumn{2}{|c|}{ Total }} \\
\hline & \multicolumn{2}{|c|}{$\begin{array}{c}\text { Tidak } \\
\text { ekslusif }\end{array}$} & \multicolumn{2}{|c|}{ Ekslusif } & & \\
\hline & $\mathrm{N}$ & $\%$ & $\mathrm{n}$ & $\%$ & $\mathrm{n}$ & $\%$ \\
\hline Tidak & & & 6 & 100 & 6 & 100 \\
\hline Pernah & 0 & .0 & & & & \\
\hline Pernah & 18 & 58.1 & 13 & 41.9 & 31 & 100 \\
\hline Total & 18 & 48.6 & 19 & 51.4 & 37 & 100 \\
\hline
\end{tabular}

Berdasarkan tabel silang 13 . Diketahui bahwa nilai $p$ pada analisis bivariat dengan uji chi square adalah 0.009 dapat diartikan bahwa ada hubungan yang signifikan antara pengalaman menyusui dengan pemberian ASI ekslusif.

\section{Hubungan Dukungan Keluarga dengan Pemberian ASI Eksklusif}


Tabel 14

Distribusi Frekuensi Ibu Menyusui Berdasarkan Dukungan Keluarga dan Pemberian ASI Ekslusif

\begin{tabular}{ccccccc}
\hline \multirow{2}{*}{$\begin{array}{c}\text { Dukungan } \\
\text { keluarga }\end{array}$} & \multicolumn{3}{c}{ Perilaku Responden } & \multicolumn{2}{c}{$\begin{array}{c}\text { Tidak } \\
\text { ekslusif }\end{array}$} & \multicolumn{2}{c}{ Ekslusif } & & Total \\
\cline { 2 - 6 } & $\mathrm{n}$ & $\%$ & $\mathrm{n}$ & $\%$ & $\mathrm{n}$ & $\%$ \\
\hline $\begin{array}{c}\text { Tidak } \\
\text { mendukung }\end{array}$ & 8 & 44.4 & & & & \\
\hline Mendukung & 10 & 52.6 & 9 & 47.4 & 19 & 100 \\
\hline Total & 18 & 48.6 & 19 & 51.4 & 37 & 100 \\
\hline \multicolumn{5}{c}{$p=0.618$} \\
\hline
\end{tabular}

Berdasarkan tabel silang 14. diketahui bahwa nilai $p$ pada analisis bivariat dengan uji chi square adalah 0.618 dapat diartikan bahwa tidak ada hubungan yang signifikan antara dukungan keluaraga dengan pemberian ASI ekslusif.

\section{Hubungan Dukungan Tenaga Kesehatan dengan Pemberian ASI Eksklusif}

Tabel 15

Distribusi Frekuensi Ibu Menyusui Berdasarkan Dukungan Tenaga Kesehatan dan Pemberian ASI Ekslusif

\begin{tabular}{cccccccc}
\hline \multirow{2}{*}{$\begin{array}{c}\text { Dukungan } \\
\text { Nakes }\end{array}$} & \multicolumn{3}{c}{ Perilaku } \\
& $\begin{array}{c}\text { Responden } \\
\text { Tidak } \\
\text { ekslusif }\end{array}$ & \multicolumn{3}{c}{ Ekslusif } & & & \\
\cline { 2 - 6 } & $\mathrm{N}$ & $\%$ & $\mathrm{n}$ & $\%$ & $\mathrm{n}$ & $\%$ \\
\hline $\begin{array}{c}\text { Tdk } \\
\text { Mendukung }\end{array}$ & 0 & & 7 & 100 & 7 & 100 \\
\hline Mendukung & 18 & 60 & 12 & 40 & 30 & 100 \\
\hline Total & 18 & 48.6 & 19 & 51.4 & 37 & 100 \\
\hline \multicolumn{7}{c}{$p=0.004$} \\
\hline
\end{tabular}

Berdasarkan tabel silang 15 diketahui bahwa nilai $p$ pada analisis bivariat dengan uji chi square adalah 0.004 dapat diartikan bahwa ada hubungan yang signifikan antara dukungan tenaga kesehatan dengan pemberian ASI ekslusif.

\section{Pembahasan}

\section{Hubungan Tingkat Pendidikan dengan Pemberian ASI Eksklusif}

Secara bivariat hubungan antara tingkat pendidikan dengan praktik pemberian ASI Eksklusif diperoleh nilai p sebesar $0.254(\mathrm{p}>\alpha)$ dapat diartikan bahwa tidak ada hubungan yang signifikan antara pendidikan dengan pemberian ASI ekslusif. Menurut Khassaw menyimpulkan bahwa ibu yang berpendidikan tinggi akan beresiko lebih tinggi untuk tidak menyusui bayinya secara ekslusif dibandingkan dengan ibu yang berpendidikan rendah. Artinya pendidikan seseorang yang tinggi tidak bisa menjamin untuk bisa berprilaku yang positif dalam menerapkan pemberian ASI ekslusif. 


\section{Hubungan Pengetahuan dengan Pemberian ASI Eksklusif}

Dari hasil uji hubungan antara pengetahuan ibu tentang ASI eksklusif dengan praktik pemberian ASI Eksklusif diperoleh nilai $\mathrm{p}<\alpha$ yang mengartikan bahwa pengetahuan ibu menyusui tentang ASI eksklusif dapat berpengaruh terhadap perilaku ibu dalam menyusui bayinya secara eksklusif.

Menurut

Notoatmodjo

menjelaskan bahwa pengetahuan merupakan domain yang sangat penting dalam membentuk tindakan prilaku seseorang. Perilaku yang didasari oleh pengetahuan akan lebih langgeng daripada perilaku yang tidak didasari oleh pengetahuan. Artinya semakin baik pengetahuan seseorang maka akan memberikan kesempatan lebih besar dibandingkan dengan orang yang mempunyai pengetahuan kurang.

Pernyataan tersebut diperkuat dengan diperolehnya nilai OR sebesar 5.409 yang mengartikan bahwa ibu menyusui yang memiliki pengetahuan kurang tentang ASI eksklusif berisiko 5,4 lebih besar untuk tidak melakukan praktek ASI ekslusif dibanding dengan ibu menyusui yang mempunyai pegetahuan baik tentang ASI eksklusif.

\section{Hubungan Sikap dengan Pemberian ASI Eksklusif}

Hasil penelitian menunjukkan bahwa nilai $\mathrm{p}$ yang diperoleh sebesar $0,969(\mathrm{p}>\alpha)$, yang berarti bahwa secara statistic sikap tidak berpengaruh terhadap perilaku ibu dalam memberikan ASI eksklusif pada bayinya.

Menurut Green sikap merupakan reaksi atau respon yang masih tertutup dari seseorang terhadap stimulus atau obyek. Sikap hal yang penting dalam kehidupan sehari-hari bila sikap sudah terbentuk dalam diri seseorang selanjutnya akan ikut menentukan perilakunya terhadap sesuatu.

Dalam konteks penelitian ini, diketahui sikap tidak berpengaruh terhadap pemberian ASI ekslusif. faktor sikap tidak signifikan karena ada faktor lain yang lebih berpengaruh. Artinya sikap seseorang yang baik tidak bisa menjamin untuk 
bisa berprilaku yang positif dalam menerapkan ASI ekslusif.

\section{Hubungan Pekerjaan dengan Pemberian ASI Eksklusif}

Dari hasil penelitian diperoleh nilai $\mathrm{p}$ sebesar $0,168 \quad(\mathrm{p}>\alpha)$ yang berarti tidak ada hubungan antara pekerjaan dengan pemberian ASI eksklusif.

Menurut Roesli bahwa peran ganda bagi ibu menyusui dapat berpengaruh terhadap pemberian ASI ekslusif kepada bayinya, dimana ibu yang bekerja tidak mempunyai banyak waktu untuk memberikan ASI kepada bayinya secara ekslusif karena harus bekerja untuk memenuhi kebutuhan hidup. Dalam kontek penelitian ini diketahui ibu yang bekerja tidak berpengaruh terhadap pemberian ASI ekslusif, faktor pekerjaan tidak signifikan karena ada faktor lain yang lebih berpengaruh, artinya pada ibu yang tidak bekerja tidak menjamin untuk bisa berprilaku yang positif dalam menerapkan ASI ekslusif.

\section{Hubungan Pengalaman Menyusui dengan Pemberian ASI Eksklusif}




\section{Hubungan Dukungan Keluarga dengan Pemberian ASI Eksklusif}

Berdasarkan tabel 14 diketahui bahwa nilai $p$ pada analisis bivariat dengan uji chi square adalah 0.618 dapat diartikan bahwa tidak ada hubungan yang signifikan antara dukungan keluaraga dengan pemberian ASI ekslusif.

Menurut Green bahwa dukungan keluarga merupakan faktor penguat yang bisa memberikan pengaruh terhadap suatu prilaku dan mempunyai kontribusi dalam menguatkan prilaku. Tetapi pada penelitian ini dukungan keluarga tidak berpengaruh terhadap pemberian ASI ekslusif karena ada faktor lain. Artinya Untuk kelangsungan pemberian ASI ekslusif tidak hanya dukungan keluarga saja tetapi harus ada faktor lain yang bisa mendukung antara pendidikan, pengetahuan, pengalaman menyusui, dukungan tenaga kesehatan dan sikap.

\section{Hubungan Dukungan Tenaga Kesehatan dengan Pemberian ASI Eksklusif}

Berdasarkan tabel 15 diketahui bahwa nilai $p$ pada analisis bivariat dengan uji chi square adalah 0.004 dapat diartikan bahwa ada hubungan yang signifikan antara dukungan tenaga kesehatan dengan pemberian ASI ekslusif.

Menurut Green dukungan petugas kesehatan merupakan faktor penguat dalam memberikan pengaruh yang berkelanjutan terhadap suatu prilaku dan mempunyai kontribusi dalam menguatkan prilaku. Artinya Petugas kesehatan memiliki peranan yang cukup penting dalam keberhasilan ibu dalam memberikan ASI ekslusif, dimana peran yang diberikan oleh petugas kesehatan adalah sebagai pemberi informasi, edukator dan motivasi ibu hingga berhasil dalam memberikan ASI ekslusif, sehingga dukungan dari petugas kesehatan sangat dibutuhkan secara terus-menerus untuk kelangsungan pemberian ASI ekslusif

\section{Simpulan}

Dari hasil penelitian diatas dapat disimpulkan bahwa hamper sebagian ibu menyusui tidak memberikan ASI secara Eksklusif pada bayinya. Pengetahuan ibu menyusui tentang ASI eskklusif, pengalaman menyusui, 
dan dukungan tenaga kesehatan memiliki hubungan/pengaruh yang bermakna terhadap pemberian ASI ekslusif; sedangkan pendidikan ibu, sikap ibu terhadap ASI eksklusif, pekerjaan ibu, dan dukungan keluarga terhadap pemberian ASI Ekslusif tidak memiliki hubungan yang bermakna terhadap pemberian ASI eksklusif yang dilakukan ibu pada bayinya.

Oleh karena itu, diharapkani Puekesmas lebih memberikan dukungan dengan cara memfasilitasi pemberian ASI ekslusif, menyediakan pojok ASI ditempat pelayanan dan pemberian Informasi melalui penyuluhan. Bidan harus lebih meningkatkan lagi dalam memotivasi ibu menyusui supaya dapat melaksanakan pemberian ASI secara Eskklusif, melalui pemberian penyuluhan maupun konseling sehingga pengetahuan ibu-ibu mengenai ASI ekslusif menjadi lebih baik.

\section{Daftar Pustaka}

Aritonang, I. Pengaruh perawatan Payudara Antenatal care terhadap Praktek ASI Ekslusif di Yogyakarta. dalam proseding Kongres Nasional Persagi dan Temu Ilmiah XII. Persagi. jakarta 2004.

Depkes RI. Panduan Manajemen Laktasi. Direktorat Gizi Masyarakat. Jakarta.2002.

Depkes RI. Konseling menyusui. Pelatihan untuk Tenaga Kesehatan. Direktorat Gizi Masyarakat. jakarta. 2002.

Depkes. Strategi Nasional Pemberian Air Susu Ibu. Depkes RI. akarta.2004.

Depkes. Manajemen Laktasi, Buku Panduan Bagi Bidan dan Petugas Kesehatan di Puskesmas. Depkes RI. Jakarta.2005.

Green, L.W. Healt promotion Planning an Edukational and Environmental Approach, second adition. Mayfild Publising Company. USA. 1991.

Notoatmodjo. Pendidikan dan Prilaku Kesehatan. Rineka Cipta.Jakarta 2003.

Notoatmodjo. Metodologi Penelitian kesehatan. Rineka Cipta. Jakarta 2003

Notoatmodjo. Promosi Kesehatan dan Aplikasinya. Rineka Cipta. Jakarta. 2005.

Perinansia. Melindungi dan Meningkatkan dan Mendukung Menyusui. binarupa Aksa Jakarta. 2002.

Roesli, U. ASI Ekslusif Tinjauan dari Aspek medis dalam Prosiding Kongres Nasional Perseagi dan Temu Ilmiah XII. Perseagi. Jakarta, 2004.

Roesli, U. Mengenal ASI Ekslusif. Trubus Agriwidya. Jakarta, 2005. 